\title{
Formation mechanism of tight coal-derived-gas reservoirs with medium-low abundance in Xujiahe Formation, central Sichuan Basin, China
}

\author{
Shengfei Qin ${ }^{\mathrm{a}, ~ *}$, Feng $\mathrm{Li}^{\mathrm{b}}$, Wei Li ${ }^{\mathrm{a}}$, Zheng Zhouc, Guoxiao Zhou
}

a Research Institute of Petroleum Exploration \& Development (RIPED), PetroChina, No.20 Xueyuan Road, P. O. Box 910, Beijing, 100083, P. R. China

b Science and Technology Management Department of PetroChina, No.9 Dongzhimen North Street, Beijing, 100007, P. R. China

c Lancaster Environment Centre, Lancaster University, Lancaster, LA1 4YQ, United Kingdom

* Corresponding author. Tel.: +86 10 83593647. E-mail address: qsf@petrochina.com.cn (S. Qin). 


\section{Abstract}

Although Xujiahe Formation source rocks in the central Sichuan Basin, China were determined to have low gas-generation intensity, several large-scale gas fields have been found associated with this formation. Thus origins and formation mechanisms of natural gas in the Xujiahe Formation have attracted attentions of many researchers. In this study, geochemistry techniques were deployed to analyze natural gas and formation water in the Xujiahe Formation tight gas reservoir, central Sichuan Basin. By considering geologic background of the gas reservoir, its formation mechanism was investigated. Research results show that the Xujiahe Formation reservoir contains an independent petroleum system, with its natural gas exclusively originated from coal-measure source rocks in the Xujiahe Formation. The formation water was determined to be $\mathrm{CaCl}_{2}$ type with high salinity. $\mathrm{H}$ and $\mathrm{O}$ isotope values are largely deviated from those of meteoric water line, indicating favourable preservation conditions for the formation water. The Xujiahe Formation is composed of multiple coal-measure source rocks and superimposed by tight sandstones. The well-developed formation water provides favourable conditions for generating water-dissolved gas. Structural movements during the Himalayan period induced significant uplifting of the central Sichuan Basin with overlying formations denudated. Consequently, natural gas dissolved in formation water experienced depressurization and exsolution. The released natural gas formed free gas phase in structural highs or provided additional natural gas supplies to existing gas reservoirs.

Key words: central Sichuan Basin, Xujiahe Formation, coal measure, tight gas reservoir, formation mechanism, water-dissolved gas 


\section{Introduction}

The central Sichuan Basin in China is an important oil and gas exploration area (Fig. 1). As early as the 1970s, oil and gas had already been found in Xujiahe Formation of central Sichuan Basin (Dai 1979). The Xujiahe Formation is composed predominantly of coal-bearing sediments of fluvial, lacustrine and swamp facies (Yang et al., 2009; Xu et al., 2009). Distributing extensively over the entire Sichuan Basin, it is the first suite of continental formations after transition from marine to continental sediments of the Sichuan Basin. Having experienced multiple sedimentary cycles (Zhang et al., 2011), the Xujiahe Formation contains multiple coal measures and tight sandstones that are superimposed. With a series of large-scale gas fields found in the West Sichuan Depression and the central Sichuan Basin, the Xujiahe Formation presents a major exploration target in the basin. Its sedimentation center resides in the West Sichuan Depression, with total thickness of $1800-2500 \mathrm{~m}$ (Yang et al., 2010). The total thickness of coal-measure source rocks is over 1000m (Liu et al., 2005; Chen et al., 2007). From the West Sichuan Depression to the central Sichuan Basin, thickness of the Xujiahe Formation decreases gradually. In the central Sichuan Basin, the Xujiahe Formation has total thickness of 550-650m, including total sandstone thickness of $200-340 \mathrm{~m}$ and total thickness of dark mudstone and coal-bearing formation of 100-300m (Yang et al., 2010).

Structures bearing large quantity of gas had been found in the Xujiahe Formation, central Sichuan Basin (Zeng et al., 2009). Existing large-scale gas fields (reservoirs) with proven reserves over $1000 \times 10^{8} \mathrm{~m}^{3}$ include Xujiahe gas reservoir of Anyue Gasfield, Guang'an Gasfield and Hechuan Gasfield. In addition, a series of medium or small gas fields have also been discovered (Fig. 1).

Formation mechanisms of the gas reservoirs in the Xujiahe Formation have been studied previously. Jiang et al. (2006) proposed a short-distance secondary gas migration mechanism based on high reservoir heterogeneity and gentle slope of the formation. Some researchers suggested that the gas reservoirs in the Xujiahe Formation were formed by expulsion of layered gas vapor from the coal source rocks, hence the gas reservoirs were distributed continuously over a large area (Zou et al., 2009; Yi et al., 2013). Other researchers suggested that the gas reservoirs were patch-like in the Xujiahe Formation, because gas-generating intensity was horizontally variable, and the heterogeneity of reservoirs was laterally strong, which made it difficult to form a large connected area of gas reservoir 
(Zhao et al., 2010). However previous studies did not take adequate account of the geological characteristics of the Xujiahe Formation, which were low gas-generation intensity of the source rocks and high saturation of formation water.

The Xujiahe Formation source rocks in central Sichuan Basin have low gas-generation intensity of less than $20 \times 10^{8} \mathrm{~km}^{2}$ in most of areas (Fig. 2), which represents the lowest gas-generation intensity observed in China for the formation of gas reservoirs with a reserve of $100 \times 10^{8} \mathrm{~m}^{3}$ (Dai et al., 1997). Previous studies show that no large-scale gas fields can be formed with such a low gas-generation intensity. Consequently, discoveries of large-scale gas fields in the central Sichuan Basin with such a low gas-generation intensity have presented challenges to the limits of the gas-generation intensity proposed by previous researchers. In addition, such discoveries require new guidelines for the formation mechanisms of such kind of natural gas reservoirs. Furthermore, the contribution of water-dissolved gas to free gas reservoirs have been neglected. Solubility of methane in formation water is determined by salinity, temperature and pressure. Under high temperature and pressure in underground formations, methane may have high solubility in water (Bonham 1978; Colin 1987). Once discharged from source rocks, natural gas may dissolve in formation water contained within source rocks or reservoir formations. Only after being saturated in water, natural gas may exist in the form of free gas. Since the Xujiahe Formation in central Sichuan Basin contains multiple source rocks and reservoir formations that are superimposed, source rocks contact directly with reservoir formations. Prior to filling of natural gas, reservoir spaces in these formations were filled with formation water. In other words, the Xujiahe Formation in central Sichuan Basin has extremely favorable conditions for formation of water-dissolved gas. Due to impacts of the Himalayan structural movements, formations in the central Sichuan Basin experienced dramatic uplifting in later stages with water-dissolved gas released to generate free gas reservoirs in upper sections of the reservoir formation. 

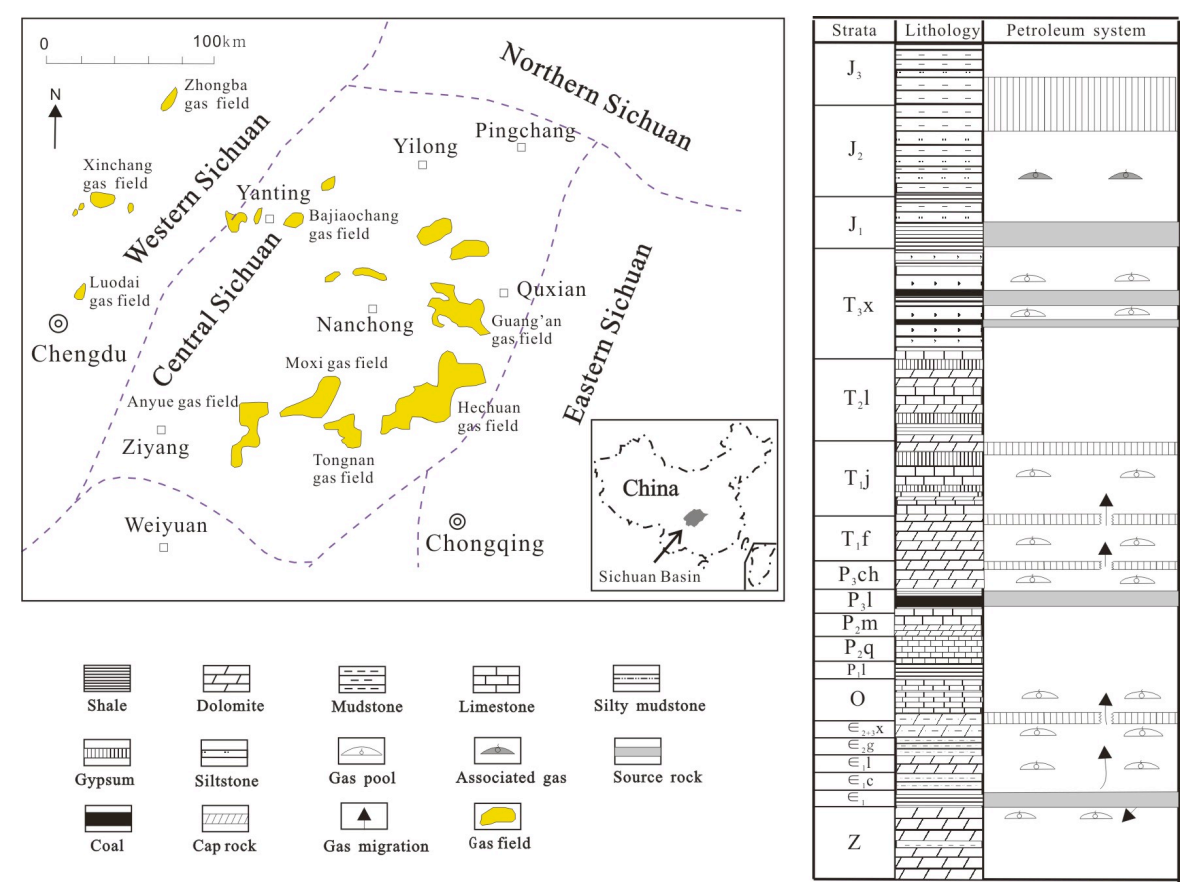

Figure 1. Map of oil and gas systems and Xujiahe gas field distribution in Central Sichuan, China

The Xujiahe Formation gas reservoirs in central Sichuan Basin have high water saturations of over $40 \%$ on average (Zhao et al., 2011). In addition, majority of gas reservoirs produced gas and water simultaneously during trial production in earlier stages. Some gas reservoirs produced water shortly after gas production in earlier development stages (Wang et al., 2005). These conditions may indicate that the formation of natural gas reservoirs in the Xujiahe Formation is possibly related to water-dissolved gas. If dissolved in water after formation, the natural gas may be preserved as long as the water can be preserved. During tectonic uplift in later stages, overlying formations experienced denudation with water-dissolved gas depressurized and released to form free gas reservoirs in relevant traps. In this way, convergence factors of natural gas can be enhanced dramatically to form large-scale gas fields in areas with relatively low gas-generation intensity.

There are many evidences available to indicate that natural gas in free gas reservoirs can originate from natural gas discharged from water. Some researchers concluded that natural gas in the Sichuan Basin was possibly formed by migration of water-dissolved gas (Wang et al., 1997; Xu et al., 2004). Natural gas in the Tarim Basin and the Tianhe gasfield were determined to be originated through releasing of water-dissolved gas (Qin et al., 2006). Water-dissolved gas might also contribute to natural gas in the Kela-2 gasfield, the major gas field for West-to-East Gas Pipeline Project of China 
(Li et al., 2003; Qin et al., 2007; Wang et al., 2004). Natural gas in the Ya-13-1 gasfield, the largest offshore gas field in China, originated also from water-dissolved gas (Chen et al., 1997). Natural gas reservoirs in North Siberia were also related to releasing of water-dissolved gas (Cramer et al., 1999; Littke et al., 1999).
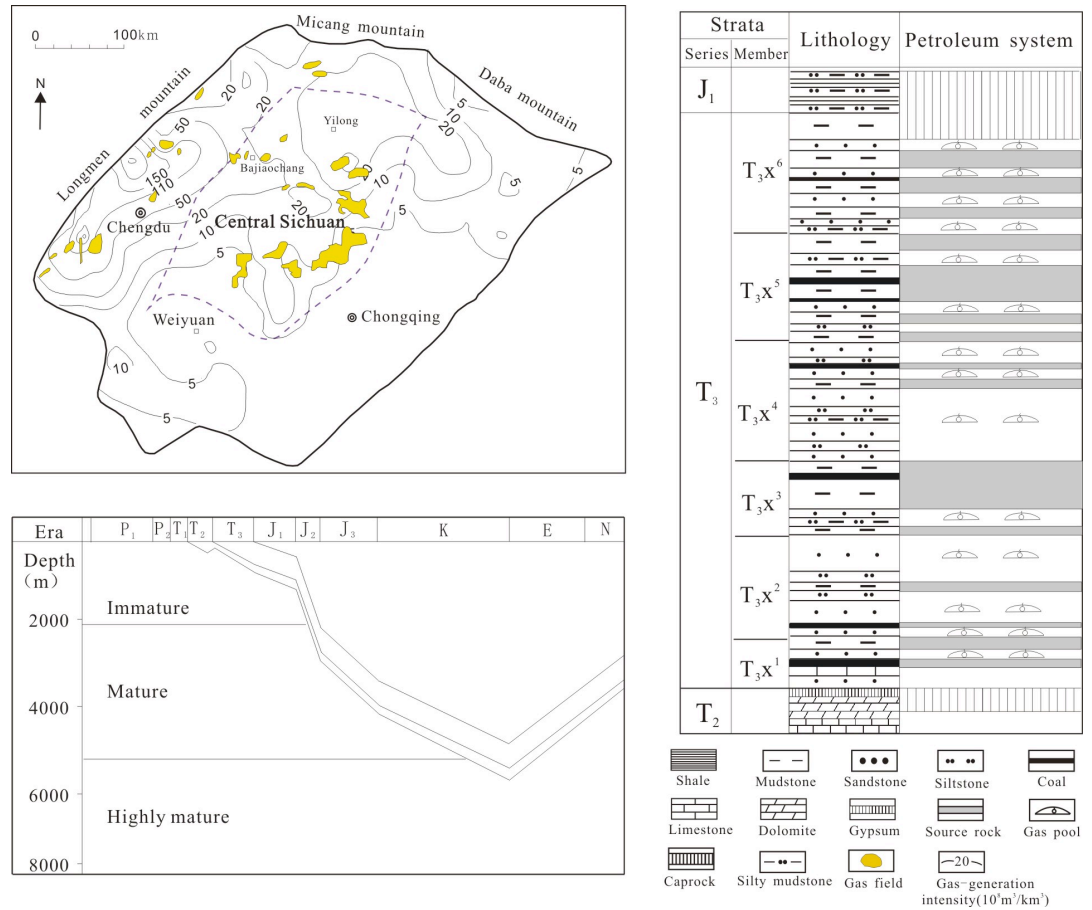

Figure 2. Hydrocarbon system and gas-generation intensity of the Xujiahe Formation in central Sichuan, China

This study aims to understand the role of water-dissolved gas in the formation of gas reservoirs in the Xujiahe Formation, central Sichuan Basin. Firstly, geochemical data of the gas are used to identify the origin of gas in the reservoirs. This can confirm that the gas is originated from local coal source rocks and exclude the possibility that gas is from the Xujiahe Formation in the western Sichuan Basin and other formations. Secondly, geological data are used to study water saturation in the Xujiahe Formation. This can demonstrate favorable conditions for the formation of water-dissolved gas. Thirdly, geochemistry of formation water is studied to prove that the formation water is preserved well to store water-dissolved gas. Fourthly, tectonic evolution of the Sichuan basin is studied to explain that water-dissolved gas can exsolve back into the gas phase and migrate into reservoirs under lowered pressure and temperature conditions. 


\section{Geologic background}

\subsection{Formations}

From top to bottom, the exposed formations in the central Sichuan Basin include Jurassic (J), Triassic $(\mathrm{T})$, Permian $(\mathrm{P})$, Ordovician $(\mathrm{O})$, Cambrian $(\in)$ and Sinian $(\mathrm{Z})$. Carboniferous $(\mathrm{C})$ and Silurian (S) are missing (Fig.1).

Due to denudation, the Jurassic formations have lower section of Upper Jurassic $\left(\mathrm{J}_{3}\right)$, together with Middle-Lower Jurassic $\left(\mathrm{J}_{1+2}\right)$ preserved. Dominated by brownish red mudstone, the Upper Jurassic formations are high-quality regional seals. Dominated by purple red, grayish green mudstone, silty mudstone and sandstone, the Middle Jurassic $\left(\mathrm{J}_{2}\right)$ formations have favorable preservation conditions. Dark shale developed in Lower Jurassic $\left(\mathrm{J}_{1}\right)$ is not only high-quality source rocks, but also favorable seals for gas reservoirs underneath.

From top to bottom, the Triassic system includes Xujiahe Formation $\left(\mathrm{T}_{3} \mathrm{x}\right)$, Leikoupo Formation $\left(T_{2} 1\right)$, Jialingjiang Formation $\left(T_{1} j\right)$ and Feixianguan Formation $\left(T_{1} f\right)$ in the upper section. From bottom up, the Xujiahe Formation contains Xu-1 Member $\left(\mathrm{T}_{3} \mathrm{x}^{1}\right)$ to Xu-6 Member $\left(\mathrm{T}_{3} \mathrm{x}^{6}\right)$, among which, the Xu-1 Member $\left(T_{3} x^{1}\right), X u-3$ Member $\left(T_{3} x^{3}\right)$ and Xu-5 Member $\left(T_{3} x^{5}\right)$ are predominantly coal-measure source rocks that might generate gas, with thin sandstone interlayers. The $\mathrm{Xu}-2\left(\mathrm{~T}_{3} \mathrm{x}^{2}\right)$ Member, $\mathrm{Xu}-4$ Member $\left(\mathrm{T}_{3} \mathrm{x}^{4}\right)$ and $\mathrm{Xu}-6$ Member $\left(\mathrm{T}_{3} \mathrm{x}^{6}\right)$ are dominated by grayish white, gray fine to medium sized sandstone, or coarse sandstone locally, with minor grayish black mudstone and thin coal beds. These formations can serve as high-quality reservoir formations (Fig. 2). Composed predominantly of dolomite with gypsum and thin grayish dark shale layers, the Leikoupo Formation can serve as high-quality seal across the study area. The Jialingjiang Formation is composed of alternating limestone and dolomite with some gypsum interlayers, which is also a favorable seal in the area. The Feixianguan Formation is composed predominantly of oolic dolomite and limestone with dissolved pores, serving as high-quality regional reservoir rocks with good porosity and permeability.

From top to bottom, the Permian system includes Changxing Formation $\left(\mathrm{P}_{3} \mathrm{ch}\right)$, Longtan Formation $\left(\mathrm{P}_{3} 1\right)$, Maokou Formation $\left(\mathrm{P}_{2} \mathrm{~m}\right)$, Qixia Formation $\left(\mathrm{P}_{2} \mathrm{q}\right)$ and Liangshan Formation $\left(\mathrm{P}_{1} 1\right)$. As a key reservoir formation, the Changxing Formation is composed predominantly of bioclastic limestone, reef limestone and dolomite. The Longtan Formation is dominated by coal measures in marine/continental 
transition facies and marine biolimestone, and it is a key contributor of source rocks. The Maokou Formation and Qixia Formation are dominated by limestone and dolomitic limestone, whereas the Liangshan Formation is dominated by shale, with some siltstone and limestone interlayers.

Dominated by biolimestone and oolitic limestone, the Ordovician system within the study area experienced denudation.

From top to bottom, the Cambrian system includes Xixiangchi Formation $\left(\in_{2+3} \mathrm{X}\right)$, Gaotai Formation $\left(\epsilon_{2} \mathrm{~g}\right)$, Longwangmiao Formation $\left(\in_{1} 1\right)$, Canglangpu Formation $\left(\in_{1} \mathrm{c}\right)$ and Qiongzhusi Formation $\left(\in_{1} q\right)$. The Longwangmiao Formation is dominated by dolomite and serves as high-quality reservoir formation. Dominated by grayish dark shale, the Qiongzhusi Formation may serve as high-quality source rocks.

From top to bottom, there are four suits of major source rocks. Each of them corresponds to one petroleum system. Vertically, they are superimposed within the central Sichuan Basin (Fig. 1). Hydrocarbons generated in the Lower Jurassic source rocks distribute predominantly in the Mid-Lower Jurassic $\left(\mathrm{J}_{1+2}\right)$ clasolite reservoir formations. Hydrocarbons generated in the Xujiahe Formation source rocks distribute in the Xujiahe Formation sandstone. Hydrocarbons generated in the Longtan Formation source rocks distribute mostly in the Upper Triassic Feixianguan Formation and Upper Permian Changxing Formation. Hydrocarbons generated in the Lower Cambrian source rocks distribute mainly in the Lower Cambrian Longwangmiao Formation $\left(\in_{1} 1\right)$.

\subsection{Structures}

According to the structural division of the Sichuan Basin, the central Sichuan Basin is also known as the "Central Sichuan gentle paleo-uplifting structure". With thin sedimentary cap rocks, minor stresses and poorly developed slip layers, the central Sichuan Basin contains gentle structures with low amplitudes (Wang et al., 2005). Early stages of Indosinian movement at the end of Middle Triassic lifted the central Sichuan Basin to form continental structures. With water retreated, large-scale in-land lakes were formed. This stage is the key period for transformation from marine sedimentation to inland lacustrine sedimentation in the Sichuan Basin. The system terminated platform sedimentation 
of carbonate rocks in the Sichuan Basin, uplifting of which induced denudation and formation of Middle Triassic erosion surface. From the Late Triassic, continental sediments were formed with formation of sedimentation assemblies composed of alternating coal-measure source rocks and sandstone.

During the Early Jurassic, the Sichuan Basin was dominated by lake-basin sediments in stable environment, which facilitated the formation of lacustrine source rocks. With the plain fluvial and shallow-water lacustrine facies that were deposited rapidly, the Middle Jurassic presented as a major sedimentation period of continental basin. From the Late Jurassic, the system changed into fluctuating lacustrine and fluvial sedimentation till the end of Late Jurassic. Due to the intensive uplifting and formation denudation during the Himalayan period, majority of areas had the Upper Jurassic and above formations missing. Thickness of formation denudation is approximately $2200-3600 \mathrm{~m}$ (Chen et al., 2007; Liu et al., 2008). Formation uplifting and denudation induced decreases in formation temperatures and pressures, and consequently hindered further hydrocarbon generation of organic matters contained in source rocks. In the central Sichuan Basin, the Himalayan movement induced the uplifting of the entire area without major faulting system. All these features are favorable for preservation of natural gas in later stages.

\subsection{Classification of gas reservoirs}

The Xujiahe Formation reservoirs in central Sichuan Basin are widely distributed with natural gas enriched in a large area. Currently, the structure is a regional monocline with higher south and lower north. Hechuan, Guang'an, Moxi-Longnüsi, Nanchong, Bajiaochang and other structures are subject to strong structural stress, with existence of short-axis anticlines and buried structures. Majority of areas have gentle structures with predominantly structural-lithologic gas reservoirs (Wang et al., 2005; Xu et al., 2009).

Statistics of tens of thousands of physical property data show that the Xujiahe Formation reservoirs have poor physical properties. With porosity of $4-8 \%$ and permeability of $0.01-1 \mathrm{mD}$, the reservoirs can be classified as low-porosity low-permeability reservoirs or extra-low porosity and extra-low permeability reservoirs (Yang et al., 2010; Zhang et al., 2011). These tight sandstone reservoirs with 
low porosity and low permeability can only produce commercial gas flows through horizontal fracturing and other EOR (Enhanced Oil Recovery) techniques (Shanley et al., 2004). With relatively high water saturation and reserve abundance of $1-3 \times 10^{8} \mathrm{~m}^{3}$, these gas reservoirs can be classified as gas reservoirs with medium-low abundance and high water content (Zhao et al., 2010).

\subsection{Development of favorable barriers on bottom and top of the Xujiahe Formation}

Unconformity surfaces between Xujiahe Formation and underlying Middle Triassic formations or overlying Jurassic formations in central Sichuan Basin are sealed off by non-permeable rocks. The formations above and below the unconformity surfaces are dominated by mudstone and gyprock. Consequently, unconformity surfaces have minor impacts on secondary migration of natural gas in the Xujiahe Formation (Jiang et al., 2006).

\section{Sampling and analytical methods}

\subsection{Sampling}

Samples of natural gas were taken from the Middle-Upper Jurassic, Upper Triassic Xujiahe Formation, Lower Triassic Feixianguan Formation, Upper Permian Changxing Formation, and Lower Cambrian Longwangmiao Formation reservoirs in central Sichuan Basin, and the Xujiahe Formation reservoirs in western Sichuan Basin. Samples of formation water were taken from the Xujiahe Formation gas reservoirs in central Sichuan Basin. To minimize the impacts of condensate water, samples of formation water were taken from producers with higher productivity and salinity. To eliminate the interferences of external factors and to ensure accuracy of the first-hand data, all such samples were taken from wells with prolonged normal production without application of de-foaming or other chemical agents recently.

Gas samples in gas layers were taken at the wellhead pressure gauge by using steel cylinders. To take such samples, the pressure gauge was dismantled before connecting the sampling steel cylinder by using sampling pipes. Prior to sampling, wellhead natural gas was used to flush the air contained in the steel cylinder thoroughly. The sampling steel cylinder was filled with wellhead natural gas up to the wellhead pressure. Water samples were taken at gas/water separator on site by using glass bottles 
of 500ml. Upon completion of sampling operations, mouths of the bottles were plugged tightly using rubber plugs before transport to lab for analyses.

\subsection{Analytical methods}

Samples were analyzed in the Key laboratory of the Research Institute of Petroleum Exploration and Development of PetroChina.

Natural gas compositions were determined using an Agilent 6890N gas chromatograph (GC) with $\mathrm{He}$ and $\mathrm{N}_{2}$ as the carrier gases. Double thermal conductivity detectors (TCD) and a $30 \mathrm{~m} \times 0.25 \mathrm{~mm} \times$ $0.25 \mu \mathrm{m}$ quartz capillary column were used. The inlet temperature was $150{ }^{\circ} \mathrm{C}$, and the TCD temperature was $200{ }^{\circ} \mathrm{C}$. The initial oven temperature was maintained at $40^{\circ} \mathrm{C}$ for $7.5 \mathrm{~min}$ isothermally, then rose from $40^{\circ} \mathrm{C}$ to $90^{\circ} \mathrm{C}$ at $15^{\circ} \mathrm{C} / \mathrm{min}$, and finally rose from $90^{\circ} \mathrm{C}$ to $180^{\circ} \mathrm{C}$ at $6^{\circ} \mathrm{C} / \mathrm{min}$.

The off-line analysis was conducted for the measurement of carbon isotopic compositions with a MAT 253 gas isotopic mass spectrometer. Natural gas samples were separated to methane, ethane, propane, butane and $\mathrm{CO}_{2}$ through the chromatography column of an SRI $8610 \mathrm{C}$ gas chromatograph, which were then transferred into combustion furnace by carrier gas $(\mathrm{He})$ and oxidized into $\mathrm{CO}_{2}$ by $\mathrm{CuO}$ at $850^{\circ} \mathrm{C}$. All of the converted species were transferred by carrier gas (He) into MS to measure the isotopic compositions. Dual inlet analysis was performed with international measurement standard of NBS-19 $\mathrm{CO}_{2}\left(\delta^{13} \mathrm{C}_{\mathrm{VPDB}}=1.95 \pm 0.04 \%\right.$, International Atomic Energy Agency, 1995) and the stable carbon isotopic values were reported in the $\delta$ notation in per mil (\%) relative to the Peedee belemnite standard (VPDB). Reproducibility and accuracy are estimated to be $\pm 0.2 \%$ with respect to VPDB standard.

Ion analysis of formation water was performed at the Geochemistry Lab of Sinopec Exploration and Development Research Institute by using Model ICS-1000 Ion Chromatography System. H and O isotopes were analyzed by Guangzhou Institute of Geochemistry of Chinese Academy of Sciences.

Stable isotope values of $\delta^{18} \mathrm{O}$ and $\delta^{2} \mathrm{H}$ of formation water were measured by mass spectrometry, with a Finnigan MAT253 after on-line pyrolysis with a Thermo Finnigan TC/EA, at the Guangzhou Institute of Geochemistry, Chinese Academy of Sciences. The $\delta^{18} \mathrm{O}$ and $\delta^{2} \mathrm{H}$ values were measured relative to internal standards that were calibrated using IAEA standards. Data were normalised in conventional $\delta(\%)$ notation. The analytical precision was $\pm 2 \%$ for $\delta^{2} \mathrm{H}$ and $\pm 0.3 \%$ for $\delta^{18} \mathrm{O}$. The 
results are shown in Table 2.

\section{Results}

\subsection{Natural gases belong to humic type}

Natural gas in the Xujiahe Formation, central Sichuan Basin, is composed predominantly of hydrocarbon gases, including methane with content of $84-94 \%$, or $89.63 \%$ on average. With dry coefficient $\left(\mathrm{C}_{1} / \mathrm{C}_{1}^{+}\right)$below $95 \%$, the natural gas has features of typical wet gas. Major non-hydrocarbon gases include $\mathrm{N}_{2}$ and $\mathrm{CO}_{2}$ with contents of $0.29-1.66 \%(0.72 \%$ on average) and $0.03-1.24 \%(0.33 \%$ on average $)$, respectively. All alkanes in the natural gas have heavy carbon isotopes, such as methane $(-42.7 \%$ o to $35.2 \%$, or $-39.5 \%$ on average $)$, ethane $(-30.0 \%$ o to $23.6 \%$, or $-27.2 \%$ on average), propane (-26.6\% to $21.7 \%$, or $-24.5 \%$ on average), and butane $(-23.6 \%$ to $18.3 \%$, or $-21.3 \%$ on average). According to the compositions of carbon isotopes of alkanes, especially carbon isotopes of ethane lower than $-28.0 \%$, the natural gas can be classified as typical humic gas in accordance with relevant national standards for oil/gas-bearing basins in China (Dai 1992) (Table 1, Fig. 3). The analytical results obtained in this study coincide well with conclusions of previous researches (Dai et al., 2009; Dai et al., 2012), suggesting that they are accurate and reliable.

\subsection{Near source reservoir-forming}

Since the source rocks in the Xujiahe Formation, central Sichuan Basin, have extremely low gas-generation intensity, many exploration experts suspected that natural gas of the Xujiahe Formation in central Sichuan Basin probably originated from source rocks with high gas-generation intensity in the Xujiahe Formation of western Sichuan Basin through lateral migration. But research results show that natural gas in the Xujiahe Formation in the western Sichuan Basin has properties significantly different from those in the central Sichuan Basin. In fact, methane and ethane in western Sichuan Basin have carbon isotopes much heavier than those in central Sichuan Basin (Fig. 3). These results coincide well with the maturity of source rocks in central Sichuan Basin and western Sichuan Basin (Liu et al., 2005; Yang et al., 2009). In addition, with upper and lower unconformity surfaces of the Xujiahe Formation sealed off by gyprocks or mudstone, it is highly impossible for natural gas to migrate laterally over long distance. Although the Xujiahe Formation contains sandstones with 
significant thicknesses over large areas, strong heterogeneity of the reservoir formation and gentle regional structures may restrict long-distance migration of hydrocarbons (Jiang et al., 2006; Xu et al., 2009). It is therefore concluded that the Xujiahe Formation in central Sichuan Basin contains gas reservoirs formed near the source.

\subsection{Independent petroleum system}

Vertically, the central Sichuan Basin contains multiple suites of diverse source rocks. In case of desirable communication through faults, reservoir formations may receive natural gas from source rocks in different layers. If this is the case, the gas reservoirs in the Xujiahe Formation would have received natural gas generated by source rocks in layers other than those in the coal-measures of the Xujiahe Formation. To answer this question, natural gas of the Xujiahe Formation in central Sichuan Basin was compared with natural gas generated by other major source rocks. Source rocks in other layers correspond to different reservoir formations. To be more specific, natural gas generated by the Lower Jurassic lacustrine argillaceous source rocks are preserved predominantly in the Middle-Upper Jurassic reservoir formations. Natural gas generated by the 
Table 1 Molecular and stable carbon isotopic values of natural gases in Xujiahe Formation of central Sichuan Basin.

\begin{tabular}{|c|c|c|c|c|c|c|c|c|c|c|c|c|c|c|c|c|}
\hline \multirow{2}{*}{ Gas field } & \multirow{2}{*}{ Well } & \multirow{2}{*}{ Strata } & \multicolumn{10}{|c|}{ Main molecular composition (\%) } & \multicolumn{4}{|c|}{$\delta^{13} \mathrm{C}, \mathrm{VPDB}(\% \mathrm{\%})$} \\
\hline & & & $\mathrm{N}_{2}$ & $\mathrm{CO}_{2}$ & $\mathrm{C}_{1}$ & $\mathrm{C}_{2}$ & $\mathrm{C}_{3}$ & $\mathrm{iC}_{4}$ & $\mathrm{nC}_{4}$ & $\mathrm{iC}_{5}$ & $\mathrm{nC}_{5}$ & $\mathrm{C}_{6+}$ & $\mathrm{C}_{1}$ & $\mathrm{C}_{2}$ & $\mathrm{C}_{3}$ & $\mathrm{C}_{4}$ \\
\hline \multirow[t]{5}{*}{ Anyue } & Yue 101-7-X1 & $\mathrm{T}_{3} \mathrm{x}^{2}$ & 0.42 & 0.39 & 87.62 & 7.73 & 2.10 & 0.53 & 0.48 & 0.23 & 0.11 & 0.32 & -42.3 & -26.8 & $3-23.4$ & -24.3 \\
\hline & Yue 101-8-X2 & $\mathrm{T}_{3} \mathrm{x}^{2}$ & 0.60 & 0.29 & 87.69 & 7.99 & 1.97 & 0.42 & 0.37 & 0.17 & 0.09 & 0.32 & -41.7 & -26.9 & -23.6 & -24.1 \\
\hline & Yue 101-9-X1 & $\mathrm{T}_{3} \mathrm{x}^{2}$ & 0.53 & 0.30 & 87.73 & 8.00 & 1.97 & 0.42 & 0.37 & 0.17 & 0.09 & 0.33 & -42.7 & -26.4 & -23.1 & -24.1 \\
\hline & Yue 101-X12 & $\mathrm{T}_{3} \mathrm{x}^{2}$ & 0.55 & 0.32 & 87.60 & 7.82 & 2.13 & 0.49 & 0.44 & 0.18 & 0.10 & 0.32 & -42.7 & -26.9 & -23.8 & -24.5 \\
\hline & Yue 101 & $\mathrm{~T}_{3} \mathrm{x}^{2}$ & 0.63 & 0.39 & 86.56 & 7.80 & 2.85 & 0.61 & 0.56 & 0.24 & 0.12 & 0.24 & -41.3 & -27.9 & -24.5 & -26.1 \\
\hline \multirow[t]{9}{*}{ Hechuan } & Hechuan 3 & $\mathrm{~T}_{3} \mathrm{x}^{2}$ & 0.56 & 0.14 & 91.67 & 5.61 & 1.11 & 0.27 & 0.18 & 0.09 & 0.04 & 0.27 & -40.4 & -25.8 & -23.9 & -21.8 \\
\hline & Hechuan 001-7 & $\mathrm{T}_{3} \mathrm{x}^{2}$ & 0.50 & 0.17 & 89.58 & 6.81 & 1.63 & 0.40 & 0.30 & 0.16 & 0.07 & 0.34 & -40.8 & -26.7 & -24.2 & -23.9 \\
\hline & Hechuan 001-13-X1 & $T_{3} x^{2}$ & 0.52 & 0.03 & 90.99 & 5.92 & 1.33 & 0.34 & 0.25 & 0.14 & 0.06 & 0.35 & -40.4 & -26.6 & -24.4 & -24.1 \\
\hline & Hechuan 108 & $\mathrm{~T}_{3} \mathrm{x}^{2}$ & 0.40 & 0.13 & 92.89 & 4.73 & 0.94 & 0.30 & 0.19 & 0.12 & 0.04 & 0.18 & -40.4 & -27.4 & -24.8 & -23.9 \\
\hline & Hechuan 001-71-X1 & $\mathrm{T}_{3} \mathrm{x}^{2}$ & 0.56 & 0.14 & 91.77 & 5.41 & 1.14 & 0.34 & 0.23 & 0.13 & 0.05 & 0.19 & -41.0 & -27.0 & -24.7 & -24.3 \\
\hline & Hechuan 107 & $\mathrm{~T}_{3} \mathrm{x}^{2}$ & 0.65 & 0.16 & 90.17 & 6.26 & 1.56 & 0.41 & 0.30 & 0.16 & 0.07 & 0.21 & -41.4 & -27.6 & -25.2 & -25.9 \\
\hline & Hechuan 001-19-X2 & $\mathrm{T}_{3} \mathrm{x}^{2}$ & 0.58 & 0.09 & 91.12 & 5.87 & 1.33 & 0.34 & 0.24 & 0.13 & 0.05 & 0.20 & -37.3 & -26.9 & -24.2 & -23.7 \\
\hline & Hechuan 001-27-X1 & $\mathrm{T}_{3} \mathrm{x}^{2}$ & 0.63 & 0.16 & 90.54 & 6.10 & 1.50 & 0.38 & 0.28 & 0.14 & 0.06 & 0.16 & -39.5 & -27.8 & -24.9 & -25.1 \\
\hline & Hechuan 001-28-X2 & $\mathrm{T}_{3} \mathrm{x}^{2}$ & 0.60 & 0.13 & 90.01 & 6.39 & 1.56 & 0.40 & 0.30 & 0.16 & 0.07 & 0.34 & -41.6 & -27.2 & -24.7 & -24.2 \\
\hline \multirow[t]{5}{*}{ Tongnan } & Tongnan 101 & $\mathrm{~T}_{3} \mathrm{x}^{2}$ & 0.93 & 0.16 & 87.27 & 7.26 & 2.74 & 0.53 & 0.53 & 0.23 & 0.11 & 0.24 & -41.5 & -28.2 & -25.0 & -26.1 \\
\hline & Tongnan 111 & $\mathrm{~T}_{3} \mathrm{x}^{2}$ & 0.72 & 0.17 & 87.95 & 7.12 & 2.48 & 0.53 & 0.48 & 0.23 & 0.10 & 0.22 & -41.1 & -27.9 & -24.7 & -25.6 \\
\hline & Tongnan 104 & $\mathrm{~T}_{3} \mathrm{x}^{2}$ & 0.70 & 0.16 & 87.88 & 7.14 & 2.52 & 0.56 & 0.50 & 0.22 & 0.10 & 0.22 & -40.9 & -27.9 & -24.6 & -25.7 \\
\hline & Tongnan 001-2 & $\mathrm{T}_{3} \mathrm{x}^{2}$ & 0.65 & 0.19 & 88.74 & 6.78 & 2.12 & 0.51 & 0.43 & 0.23 & 0.10 & 0.25 & -40.5 & -27.4 & -24.4 & -25.6 \\
\hline & Tongnan 105 & $\mathrm{~T}_{3} \mathrm{x}^{2}$ & 0.60 & 0.14 & 89.57 & 6.49 & 1.85 & 0.43 & 0.35 & 0.19 & 0.08 & 0.30 & -40.3 & -27.5 & -24.5 & -25.0 \\
\hline Longnvsi & Nv 103 & $\mathrm{~T}_{3} \mathrm{x}^{2}$ & 0.62 & 0.16 & 90.10 & 6.49 & 1.55 & 0.37 & 0.26 & 0.14 & 0.05 & 0.26 & -39.0 & -26.7 & -23.8 & -23.7 \\
\hline \multirow[t]{8}{*}{ Hechuan } & Hechuan 124 & $\mathrm{~T}_{3} \mathrm{x}^{2}$ & 0.78 & 0.15 & 89.19 & 6.57 & 1.68 & 0.44 & 0.33 & 0.21 & 0.09 & 0.56 & -40.4 & -27.4 & -24.5 & -25.3 \\
\hline & Hechuan 106 & $\mathrm{~T}_{3} \mathrm{x}^{2}$ & 0.53 & 0.36 & 89.27 & 6.75 & 1.73 & 0.40 & 0.31 & 0.17 & 0.07 & 0.41 & -39.4 & -26.9 & -24.1 & -24.6 \\
\hline & Hechuan 001-30-X1 & $\mathrm{T}_{3} \mathrm{x}^{2}$ & 0.87 & 0.22 & 90.31 & 6.07 & 1.36 & 0.36 & 0.26 & 0.16 & 0.06 & 0.33 & -39.5 & -27.1 & -24.3 & -24.8 \\
\hline & Hechuan 108 & $\mathrm{~T}_{3} \mathrm{x}^{2}$ & 0.77 & 0.43 & 89.80 & 6.42 & 1.43 & 0.34 & 0.27 & 0.16 & 0.07 & 0.31 & -38.6 & -27.1 & -25.2 & -26.3 \\
\hline & Hechuan 125 & $\mathrm{~T}_{3} \mathrm{x}^{2}$ & 0.69 & 0.12 & 92.83 & 4.82 & 0.82 & 0.23 & 0.15 & 0.11 & 0.04 & 0.19 & -37.2 & -26.2 & -24.5 & -26.3 \\
\hline & Hechuan 001-18-X2 & $\mathrm{T}_{3} \mathrm{x}^{2}$ & 0.68 & 0.15 & 89.92 & 6.67 & 1.57 & 0.29 & 0.25 & 0.12 & 0.05 & 0.30 & -38.8 & -27.3 & -24.6 & \\
\hline & Hechuan 001-2 & $\mathrm{T}_{3} \mathrm{x}^{2}$ & 0.78 & 0.18 & 89.53 & 6.71 & 1.68 & 0.39 & 0.28 & 0.15 & 0.06 & 0.24 & -39.3 & -26.9 & -23.9 & -24.0 \\
\hline & Hechuan 129 & $\mathrm{~T}_{3} \mathrm{x}^{2}$ & 0.98 & 0.28 & 93.55 & 4.34 & 0.59 & 0.10 & 0.07 & 0.03 & 0.01 & 0.05 & -35.2 & -24.5 & -22.1 & -21.6 \\
\hline Suinan & Sui 56 & $\mathrm{~T}_{3} \mathrm{x}^{2}$ & 0.45 & 0.53 & 87.49 & 7.10 & 2.66 & 0.62 & 0.55 & 0.25 & 0.11 & 0.24 & -40.1 & -27.2 & -23.8 & -24.2 \\
\hline Jinhua & Jin 2 & $\mathrm{~T}_{3} \mathrm{x}^{2+4}$ & 1.66 & 0.59 & 89.51 & 5.78 & 1.60 & 0.28 & 0.27 & 0.09 & 0.05 & 0.17 & -37.3 & -25.4 & -23.2 & \\
\hline Suinan & Sui 37 & $\mathrm{~T}_{3} \mathrm{x}^{2+4}$ & 0.92 & 0.84 & 84.09 & 7.85 & 3.59 & 0.72 & 0.79 & 0.34 & 0.21 & 0.65 & -41.3 & -27.8 & -24.5 & -24.9 \\
\hline \multirow[t]{2}{*}{ Nanchong } & Xi 20 & $\mathrm{~T}_{3} \mathrm{x}^{4}$ & 0.64 & 0.36 & 88.68 & 6.07 & 2.41 & 0.48 & 0.52 & 0.21 & 0.12 & 0.51 & -41.4 & -28.3 & -25.3 & -24.4 \\
\hline & Xi 51 & $\mathrm{~T}_{3} \mathrm{x}^{4}$ & 0.63 & 0.23 & 87.71 & 5.85 & 1.92 & 0.38 & 0.45 & 0.29 & 0.21 & 2.33 & -39.9 & -27.2 & -24.5 & -24.0 \\
\hline \multirow[t]{9}{*}{ Guang'an } & Guang'an 002-23 & $\mathrm{T}_{3} \mathrm{x}^{6}$ & 1.19 & 0.35 & 89.31 & 6.15 & 1.85 & 0.34 & 0.33 & 0.13 & 0.07 & 0.28 & -38.5 & -27.5 & -26.1 & -25.3 \\
\hline & Guang'an 51 & $\mathrm{~T}_{3} \mathrm{x}^{6}$ & 0.40 & 0.37 & 89.88 & 6.32 & 1.88 & 0.34 & 0.33 & 0.13 & 0.07 & 0.28 & -38.4 & -27.6 & -26.0 & -25.3 \\
\hline & Guang'an 002-X70 & $\mathrm{T}_{3} \mathrm{x}^{6}$ & 0.55 & 0.30 & 89.42 & 6.40 & 1.98 & 0.38 & 0.38 & 0.16 & 0.09 & 0.34 & -38.6 & -27.8 & -26.3 & -25.4 \\
\hline & Guang'an 002-40 & $T_{3} x^{6}$ & 0.82 & 0.59 & 89.01 & 6.33 & 2.01 & 0.38 & 0.38 & 0.15 & 0.08 & 0.25 & -38.7 & -27.9 & -26.4 & -25.8 \\
\hline & Guang'an 002-X37 & $\mathrm{T}_{3} \mathrm{x}^{6}$ & 0.53 & 0.34 & 89.18 & 6.57 & 2.07 & 0.39 & 0.38 & 0.15 & 0.08 & 0.31 & -38.3 & -27.8 & -26.0 & -25.4 \\
\hline & Guang'an $002-X 38$ & $T_{3} x^{6}$ & 0.61 & 0.39 & 88.76 & 6.63 & 2.23 & 0.42 & 0.41 & 0.16 & 0.09 & 0.30 & -39.4 & -27.8 & -26.0 & \\
\hline & Guang'an 002-X72 & $T_{3} x^{6}$ & 0.50 & 0.49 & 88.94 & 6.30 & 1.91 & 0.37 & 0.37 & 0.17 & 0.10 & 0.85 & -38.2 & -27.6 & -26.3 & -25.4 \\
\hline & Guang'an $02-11-\mathrm{H} 2$ & $T_{3} x^{6}$ & 0.70 & 0.59 & 89.58 & 6.22 & 1.80 & 0.33 & 0.31 & 0.13 & 0.07 & 0.27 & -38.3 & -27.7 & -26.3 & -25.1 \\
\hline & Guang 19 & $T_{3} x^{6}$ & 0.60 & 0.26 & 90.34 & 5.90 & 1.76 & 0.32 & 0.33 & 0.13 & 0.09 & 0.27 & -38.7 & -27.9 & -26.6 & -26.1 \\
\hline Bajiaochuang & Jiao 47 & $T_{3} x^{6}$ & 0.64 & 0.42 & 89.92 & 5.60 & 1.93 & 0.33 & 0.37 & 0.13 & 0.09 & 0.57 & -38.7 & -26.1 & -24.1 & -23.4 \\
\hline Guanyinchang & Yin 10 & $\mathrm{~T}_{3} \mathrm{x}^{6}$ & 1.09 & 0.39 & 89.36 & 6.03 & 1.82 & 0.45 & 0.39 & 0.19 & 0.09 & 0.19 & -38.6 & -26.9 & -23.7 & -24.6 \\
\hline \multirow[t]{5}{*}{ Longgang } & Longgang 9 & $\mathrm{~T}_{3} \mathrm{x}^{6}$ & 0.41 & 0.59 & 93.10 & 4.80 & 0.70 & 0.11 & 0.09 & 0.03 & 0.02 & 0.12 & -41.5 & -26.2 & -24.1 & -22.1 \\
\hline & Longgang 3 & $\mathrm{~T}_{3} \mathrm{x}^{6}$ & 1.18 & 0.39 & 92.62 & 4.42 & 0.90 & 0.19 & 0.14 & 0.05 & 0.02 & 0.06 & -37.1 & -25.4 & -23.8 & -22.1 \\
\hline & Longgang 17 & $\mathrm{~T}_{3} \mathrm{x}^{6}$ & 0.45 & 0.43 & 92.16 & 5.38 & 0.84 & 0.19 & 0.14 & 0.08 & 0.04 & 0.28 & -38.7 & -25.1 & -23.6 & -21.0 \\
\hline & Longgang 18 & $T_{3} x^{6}$ & 0.50 & 0.38 & 93.83 & 4.40 & 0.55 & 0.09 & 0.06 & 0.02 & 0.01 & 0.13 & -38.1 & -23.6 & -21.7 & -23.6 \\
\hline & Longgang 176 & $T_{3} x^{6}$ & 0.29 & 0.54 & 91.32 & 5.88 & 1.19 & 0.21 & 0.18 & 0.06 & 0.03 & 0.28 & -39.9 & -24.7 & -22.7 & -21.5 \\
\hline
\end{tabular}




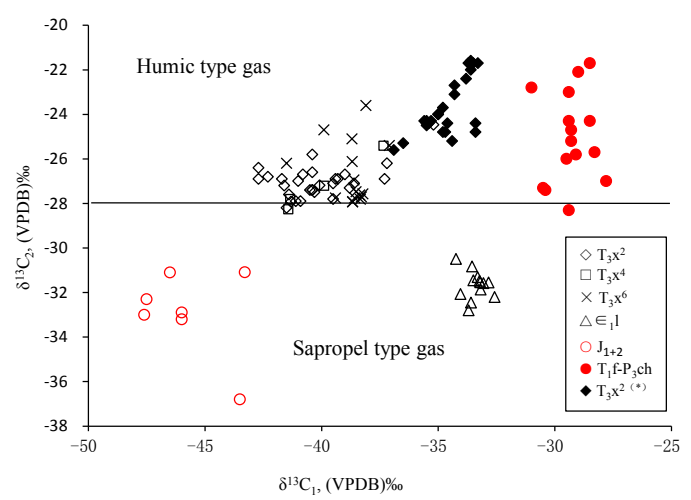

Figure 3. Comparison of $\delta^{13} \mathrm{C}_{1}$ and $\delta^{13} \mathrm{C}_{2}$ of natural gas in main gas fields in central Sichuan Basin

Upper Permian Longtan Formation coal-measure source rocks are preserved predominantly in Changxing Formation and Feixianguan Formation. Natural gas generated by the Lower Cambrian Qiongzhusi Formation source rocks are preserved predominantly in Longwangmiao Formation. Through comparison, it was determined that natural gases produced by source rocks in various layers of the central Sichuan Basin may have different geochemistry properties (Fig. 3). Natural gases of Jurassic and Longwangmiao Formation are oil type. Source rocks in Jurassic formation have lower maturity, whereas those in the Longwangmiao Formation have higher maturity. As far as methane carbon isotope ratios are concerned, the Longwangmiao Formation contains natural gas with methane carbon isotope much heavier than that of the Jurassic natural gas. Natural gas contained in both Changxing and Feixianguan formations can be classified as coal-derived gas with preservation formation in carbonate rocks. These formations contain $\mathrm{H}_{2} \mathrm{~S}$ (Qin et al., 2016). Since source rocks have high maturity, methane carbon isotopes are also heavy.

It can be seen that source rocks and reservoir formations in the Xujiahe Formation, central Sichuan Basin, jointly formed independent source-reservoir system. With no contribution from natural gas originated from other source rocks, these formations contain only natural gas generated and preserved within them.

\subsection{Well-preserved primary formation water}

Once generated, water-dissolved gas would require favorable conditions to remain in the water. According to the analytical data obtained from formation water produced in 27 producers in the Xujiahe Formation, central Sichuan Basin (Table 2), the formation water of Dengying Formation in 
Weiyuan gasfield contains highest $\mathrm{K}^{+}, \mathrm{Na}^{+}$and $\mathrm{Cl}^{-}$and low $\mathrm{HCO}_{3}^{-}$. There are also trace amounts of $\mathrm{SO}_{4}{ }^{2-}$. The water has high salinity of $111-365 \mathrm{~g} / \mathrm{L}$, or $234 \mathrm{~g} / \mathrm{L}$ on average. Since the formation water is $\mathrm{CaCl}_{2}$ type, relevant gas fields have favorable conditions for preservation of water to promote the preservation of natural gas dissolved in water.

Analyses of $\mathrm{H}$ and $\mathrm{O}$ isotopes were performed for formation water of Xujiahe Formation in central Sichuan Basin. Formation water samples were scattered far from the meteoric water line, but samples taken from surface rivers in different parts of the Sichuan Basin fall in vicinity of the meteoric water line. Test results coincide very well with actual conditions. It can be concluded that formation water of the Xujiahe Formation in central Sichuan Basin can be classified as primary water preserved under favorable conditions without experiencing destruction by later-stage geologic evolution (Fig. 4). The Xujiahe Formation in the central Sichuan Basin provides favorable conditions for the preservation of formation water. This also indicates that natural gas dissolved in formation water can be preserved on a geological time scale. 
Table 2 Geochemical characteristics of formation water in gas reservoirs of Xujiahe Formation in central Sichuan Basin.

\begin{tabular}{|c|c|c|c|c|c|c|c|c|c|c|c|c|c|c|}
\hline \multirow{2}{*}{ Gas field } & \multirow{2}{*}{ Well } & \multirow{2}{*}{ Strata } & \multicolumn{8}{|c|}{ Main ion content $(\mathrm{mg} / \mathrm{L})$} & \multirow{2}{*}{$\begin{array}{c}\text { Salinity } \\
(\mathrm{g} / \mathrm{L})\end{array}$} & \multirow{2}{*}{$\begin{array}{c}\text { Water } \\
\text { type }\end{array}$} & \multirow{2}{*}{$\begin{array}{l}\delta^{18} \mathrm{O} \\
(\% \mathrm{o})\end{array}$} & \multirow{2}{*}{$\begin{array}{c}\delta \mathrm{D} \\
(\% \text { ) }\end{array}$} \\
\hline & & & $\mathrm{K}^{+}$ & $\mathrm{Na}^{+}$ & $\mathrm{Ca}^{2+}$ & $\mathrm{Mg}^{2+}$ & $\mathrm{Ba}^{2+}$ & $\mathrm{SO}_{4}{ }^{2-}$ & $\mathrm{Cl}^{-}$ & $\mathrm{HCO}_{3}^{-}$ & & & & \\
\hline \multirow[t]{4}{*}{ Tongnan } & $\begin{array}{l}\text { Tongnan } \\
101\end{array}$ & $\mathrm{~T}_{3} \mathrm{x}^{2}$ & 1936 & 47200 & 16421 & 1861 & 144 & 4 & 215986 & 10 & 284 & $\mathrm{CaCl}_{2}$ & -2.33 & -42.0 \\
\hline & $\begin{array}{l}\text { Tongnan } \\
104\end{array}$ & $\mathrm{~T}_{3} \mathrm{x}^{2}$ & 1613 & 42170 & 17547 & 1892 & 135 & 4 & 215973 & 49 & 279 & $\mathrm{CaCl}_{2}$ & -1.19 & -37.6 \\
\hline & $\begin{array}{l}\text { Tongnan } \\
001-2\end{array}$ & $\mathrm{~T}_{3} \mathrm{x}^{2}$ & 1451 & 49300 & 22947 & 2108 & 184 & 6 & 139859 & 25 & 216 & $\mathrm{CaCl}_{2}$ & -1.11 & -38.2 \\
\hline & $\begin{array}{l}\text { Tongnan } \\
105\end{array}$ & $\mathrm{~T}_{3} \mathrm{x}^{2}$ & 1678 & 46430 & 17979 & 2058 & 173 & 13 & 226129 & 25 & 295 & $\mathrm{CaCl}_{2}$ & -0.91 & -35.8 \\
\hline \multirow[t]{5}{*}{ Hechuan } & $\begin{array}{l}\text { Hechuan } \\
124\end{array}$ & $\mathrm{~T}_{3} \mathrm{x}^{2}$ & 1454 & 50790 & 21989 & 2369 & 170 & 11 & 242037 & 12 & 319 & $\mathrm{CaCl}_{2}$ & -0.71 & -34.9 \\
\hline & $\begin{array}{l}\text { Hechuan } \\
106\end{array}$ & $\mathrm{~T}_{3} \mathrm{x}^{2}$ & 1099 & 35810 & 19600 & 2298 & 181 & 44 & 237641 & 49 & 297 & $\mathrm{CaCl}_{2}$ & -1.17 & -36.6 \\
\hline & $\begin{array}{l}\text { Hechuan } \\
1-30-X 1\end{array}$ & $\mathrm{~T}_{3} \mathrm{x}^{2}$ & 5565 & 25760 & 5419 & 652 & 189 & 42 & 110667 & 62 & 148 & $\mathrm{CaCl}_{2}$ & -1.04 & -30.5 \\
\hline & $\begin{array}{l}\text { Hechuan } \\
1-12-\mathrm{X} 2\end{array}$ & $\mathrm{~T}_{3} \mathrm{x}^{2}$ & 1849 & 48370 & 20550 & 2249 & 174 & 9 & 152275 & 37 & 226 & $\mathrm{CaCl}_{2}$ & -1.06 & -36.2 \\
\hline & $\begin{array}{l}\text { Hechuan } \\
129\end{array}$ & $\mathrm{~T}_{3} \mathrm{x}^{2}$ & 2490 & 57880 & 30130 & 2853 & 149 & 28 & 228995 & 37 & 323 & $\mathrm{CaCl}_{2}$ & -0.68 & -33.6 \\
\hline \multirow[t]{8}{*}{ Guang'an } & $\begin{array}{l}\text { Guang'an } \\
002-\mathrm{H} 4\end{array}$ & $T_{3} x^{6}$ & 815 & 42870 & 16300 & 1866 & 138 & 15 & 159600 & 12 & 222 & $\mathrm{CaCl}_{2}$ & -3.46 & -44.6 \\
\hline & $\begin{array}{l}\text { Guang'an } \\
002-40\end{array}$ & $\mathrm{~T}_{3} \mathrm{x}^{6}$ & 807 & 4433 & 17590 & 1705 & 152 & 16 & 172834 & 37 & 198 & $\mathrm{CaCl}_{2}$ & -3.53 & -43.7 \\
\hline & $\begin{array}{l}\text { Guang'an } \\
02-X 38\end{array}$ & $\mathrm{~T}_{3} \mathrm{x}^{6}$ & 674 & 38960 & 13740 & 1535 & 141 & 27 & 153709 & 74 & 209 & $\mathrm{CaCl}_{2}$ & -3.24 & -47.5 \\
\hline & $\begin{array}{l}\text { Guang'an } \\
\text { 002-H1 }\end{array}$ & $\mathrm{T}_{3} \mathrm{x}^{6}$ & 830 & 45750 & 20300 & 1882 & 162 & 19 & 209990 & 37 & 279 & $\mathrm{CaCl}_{2}$ & -3.47 & -45.1 \\
\hline & $\begin{array}{l}\text { Guang'an } \\
02-X 27\end{array}$ & $\mathrm{~T}_{3} \mathrm{x}^{6}$ & 922 & 37900 & 19560 & 1931 & 148 & 17 & 201239 & 62 & 262 & $\mathrm{CaCl}_{2}$ & -4.09 & -42.9 \\
\hline & $\begin{array}{l}\text { Guang'an } \\
125\end{array}$ & $\mathrm{~T}_{3} \mathrm{x}^{4}$ & 3763 & 53830 & 21380 & 1767 & 162 & 7 & 277473 & 25 & 358 & $\mathrm{CaCl}_{2}$ & -1.86 & -44.6 \\
\hline & $\begin{array}{l}\text { Guang'an } \\
114\end{array}$ & $\mathrm{~T}_{3} \mathrm{x}^{6}$ & 603 & 27540 & 13930 & 1461 & 149 & 8 & 191317 & 111 & 235 & $\mathrm{CaCl}_{2}$ & -3.75 & -43.2 \\
\hline & $\begin{array}{l}\text { Guang'an } \\
2-11-\mathrm{H} 2\end{array}$ & $\mathrm{~T}_{3} \mathrm{x}^{6}$ & 1264 & 52890 & 26860 & 2135 & 172 & 12 & 281157 & 37 & 365 & $\mathrm{CaCl}_{2}$ & -3.42 & -38.1 \\
\hline \multirow[t]{2}{*}{ Nanchong } & Xi 35-1 & $\mathrm{T}_{3} \mathrm{x}^{6}$ & 525 & 33900 & 15470 & 1754 & 147 & 8 & 58864 & 87 & 111 & $\mathrm{CaCl}_{2}$ & -3.08 & -52.3 \\
\hline & Xi 20 & $\mathrm{~T}_{3} \mathrm{x}^{4}$ & 951 & 39550 & 17710 & 1855 & 152 & 4 & 96699 & 223 & 157 & $\mathrm{CaCl}_{2}$ & -2.31 & -45.9 \\
\hline Bajiaochang & Jiao 47 & $T_{3} x^{6}$ & 680 & 32210 & 5327 & 665 & 187 & 11 & 92588 & 383 & 132 & $\mathrm{CaCl}_{2}$ & -1.94 & -50.9 \\
\hline Jinhua & Jin 2 & $\mathrm{~T}_{3} \mathrm{x}^{2+4}$ & 726 & 26500 & 5214 & 643 & 151 & 9 & 87496 & 136 & 121 & $\mathrm{CaCl}_{2}$ & -2.39 & -53.5 \\
\hline \multirow[t]{2}{*}{ Suinan } & Sui 37 & $\mathrm{~T}_{3} \mathrm{x}^{2+4}$ & 1610 & 51770 & 21905 & 2259 & 155 & 23 & 197512 & 37 & 275 & $\mathrm{CaCl}_{2}$ & -1.02 & -40.8 \\
\hline & Sui 56 & $\mathrm{~T}_{3} \mathrm{x}^{2}$ & 2032 & 56740 & 25829 & 2665 & 186 & 12 & 57922 & 37 & 145 & $\mathrm{CaCl}_{2}$ & -0.19 & -35.3 \\
\hline Hebaochang & $\begin{array}{l}\text { Baoqian } \\
001-6\end{array}$ & $\mathrm{~T}_{3} \mathrm{x}^{4}$ & 2177 & 37990 & 11933 & 1837 & 3 & 79 & 151700 & 87 & 206 & $\mathrm{CaCl}_{2}$ & 1.00 & -23.3 \\
\hline Hebaochang & Bao 16 & $\mathrm{~T}_{3} \mathrm{x}^{4}$ & 1542 & 39570 & 11400 & 1338 & 175 & 3 & 116243 & 99 & 170 & $\mathrm{CaCl}_{2}$ & -0.81 & -26.2 \\
\hline Hebaochang & Bao 36 & $T_{3} x^{4}$ & 2167 & 42260 & 15800 & 1565 & 160 & 9 & 180843 & 124 & 243 & $\mathrm{CaCl}_{2}$ & -1.82 & -29.7 \\
\hline Anyue & Yue 101 & $\mathrm{~T}_{3} \mathrm{x}^{2}$ & 3288 & 39890 & 18238 & 1674 & 171 & 13 & 169296 & 62 & 233 & $\mathrm{CaCl}_{2}$ & -3.59 & -43.4 \\
\hline $\begin{array}{l}\text { Surface } \\
\text { water }\end{array}$ & Fu River & & 2 & 21 & 24 & 6 & 0 & 66 & 51 & 186 & 0.4 & & -8.74 & -63.6 \\
\hline $\begin{array}{l}\text { Surface } \\
\text { water }\end{array}$ & \multicolumn{2}{|c|}{ Jialing River } & 2 & 28 & 83 & 11 & 1 & 31 & 13 & 37 & 0.2 & & -8.49 & -59.8 \\
\hline $\begin{array}{l}\text { Surface } \\
\text { water }\end{array}$ & \multicolumn{2}{|l|}{ Tuo River } & 3 & 20 & 66 & 9 & 0 & 84 & 25 & 173 & 0.4 & & -7.34 & -50.7 \\
\hline
\end{tabular}




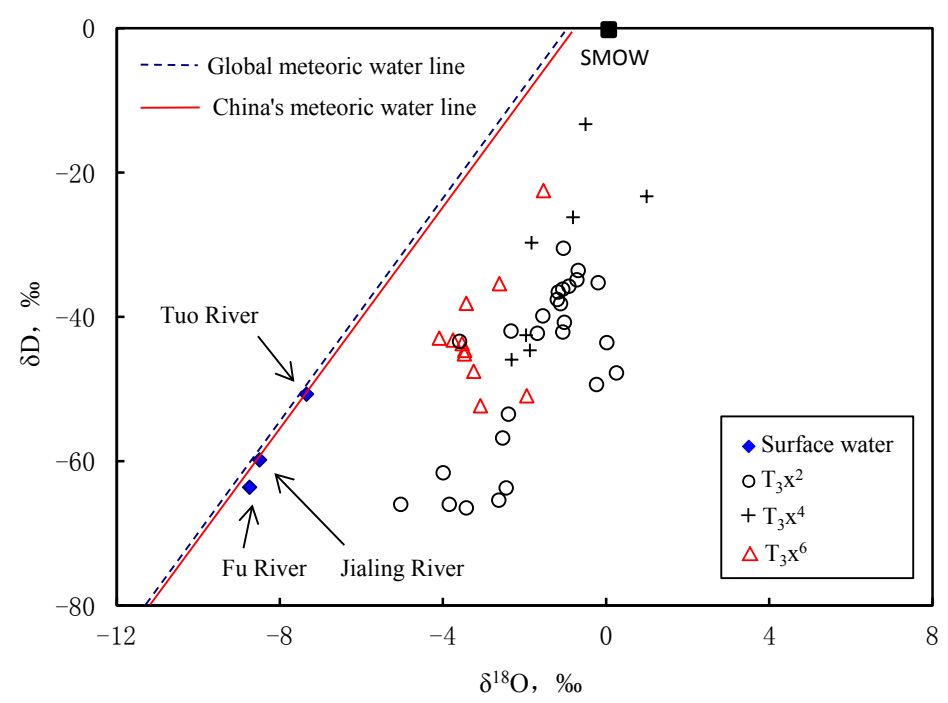

Figure 4. Distribution of Hydrogen and Oxygen Isotopes of Formation Water in Xujiahe Formation, central Sichuan Basin.

\section{Discussion}

\subsection{Favorable conditions for water-dissolved gas formation}

5.1.1. Multiple suites of source rocks and reservoir formations are superimposed vertically and distributed extensively

Formations in the central Sichuan Basin are distributed on gentle slopes. Multiple coal-measure source rocks and reservoir formations are superimposed vertically and distributed extensively over the entire central Sichuan Basin. Source rocks are distributed not only in $\mathrm{T}_{3} \mathrm{x}^{1}, \mathrm{~T}_{3} \mathrm{x}^{3}$ and $\mathrm{T}_{3} \mathrm{x}^{5}$, but also in $\mathrm{T}_{3} \mathrm{x}^{2}, \mathrm{~T}_{3} \mathrm{x}^{4}$ and $\mathrm{T}_{3} \mathrm{x}^{6}$ where thin coal layers and dark mudstone are endowed. All of these source rocks mainly produce natural gas. In addition, $\mathrm{T}_{3} \mathrm{x}^{1}, \mathrm{~T}_{3} \mathrm{x}^{3}$ and $\mathrm{T}_{3} \mathrm{x}^{5}$ contain not only source rocks, but also multiple sandstone reservoirs (Fig. 2). The central Sichuan Basin has relatively stable structures. Prior to the Himalayan tectonic uplifting, there was no fault communication or extensive contact among source rocks and reservoir formations. Instead source rocks contained in each layer continuously supplied gas to overlying reservoir formations. First of all, natural gas might easily dissolve in water contained within the sandstone to form water-dissolved gas. Accumulations of free gas could be formed only after methane was saturated in water.

\subsubsection{Sufficient formation water}

There are several gas/water systems developed vertically in the Xujiahe Formation, central Sichuan 
Basin. Internally, these gas/water systems contain mostly gas in upper sections and water in lower sections. With existence of the wide gas/water transitional belt, gas and water are not separated thoroughly (Tian et al., 2009). From top to bottom, each independent gas/water system has mobile water saturation increased gradually. Generally gas-bearing formations are distributed predominantly in structural highs, whereas gas/water and water-bearing layers are distributed on gentle slopes (Hao et al., 2010a; 2010b).

The Xujiahe Formation in central Sichuan Basin is dominated primarily by lithologic gas reservoirs and structural-lithologic gas reservoirs, with high water saturation (Table 3). With complicated gas/water relationships, gas reservoirs are diverse in types and subject to control of source rocks, reservoir formations, paleo-structures and present structures (Xie et al., 2008). In addition, sufficient formation water provides essential carrier for water-dissolved gas.

Table 3 Moisture saturation of typical gas reservoirs of Xujiahe Formation in central Sichuan

\begin{tabular}{lcccc}
\hline Gas field & Strata & \multicolumn{3}{c}{ Basin (Xie et al., 2008). } \\
$(\%)$ & $\begin{array}{c}\text { Permeability } \\
\left(10^{-3} \mu \mathrm{m}\right)\end{array}$ & $\begin{array}{c}\text { Water } \\
(\%)\end{array}$ \\
\hline Guang'an & $\mathrm{T}_{3} \mathrm{x}^{6}$ & 9.80 & 0.3740 & 46.30 \\
Bajiaochang & $\mathrm{T}_{3} \mathrm{x}^{4}$ & 7.87 & 0.6290 & 59.24 \\
Lianchi & $\mathrm{T}_{3} \mathrm{x}^{4}$ & 6.29 & 0.6000 & 48.60 \\
Chongxi & $\mathrm{T}_{3} \mathrm{x}^{4}$ & 7.15 & 2.1100 & 45.00 \\
Hebaochang & $\mathrm{T}_{3} \mathrm{x}^{4}$ & 9.42 & 0.5680 & 47.00 \\
Hebaochang & $\mathrm{T}_{3} \mathrm{x}^{2}$ & 12.70 & 1.790 & 45.00 \\
\hline
\end{tabular}

\subsection{Geologic conditions for releasing water-dissolved gas}

Possibility of releasing water-dissolved gas from the water to generate free gas may depend on changes in temperatures, pressures and salinity. When temperature is below $80^{\circ} \mathrm{C}$, solubility of methane in water may decrease with increase of temperature. When temperature is over $80^{\circ} \mathrm{C}$, solubility of methane in water may increase with increase of temperature. In addition, the solubility may increase significantly with increase of pressure and decrease with increase of salinity (Colin 1987; Duan 1992). Tectonic uplifting and subsequent denudation of overlying formations may facilitate decrease of temperatures and pressures. However, the natural gas can be released from the water only under proper geologic conditions.

\subsubsection{Tectonic uplifting in later stages}

As mentioned in the sections above, the central Sichuan Basin experienced significant uplifting and 
denudation with average uplifting amplitude and denudation thickness of near $3000 \mathrm{~m}$ due to the Himalayan movement at the end of Cretaceous. With large-scale denudation of overlying formations, temperatures and pressures of fluids in gas reservoirs decreased dramatically to promote pressure decreasing and releasing of water-dissolved gas.

\subsubsection{Uplifting-induced structural fractures facilitate flow of reservoir fluids}

Reservoirs of the Xujiahe Formation in central Sichuan Basin can be classified as tight sandstone reservoirs with low permeability and low porosity. Miniature structural fractures induced by structural movements could effectively enhance properties and seepage conditions of the reservoirs (Bian et al., 2009; Che et al., 2007). Dynamic production data show that such fractures are key components in the Upper Triassic reservoirs, since they are major flowing channels and essential reservoir spaces. In view of origins, these miniature fractures are predominantly structural fractures (Xie et al., 2009).

\subsubsection{Volume of released water-dissolved gas}

Present temperature and pressure of the Xujiahe Formation in central Sichuan Basin are determined to be $70^{\circ} \mathrm{C}$ and $30 \mathrm{MPa}$, respectively. The Xujiahe Formation has buried depths of 5000-6000 m (Jiang et al., 2006). Study on fluid inclusions show that paleo-temperature of the Xujiahe Formation can reach $150^{\circ} \mathrm{C}$ (Tao et al., 2009). Taking a paleo-geothermal gradient of $2.8^{\circ} \mathrm{C} / 100 \mathrm{~m}$ (Wang eta al., 1998) and denuded thickness of $3000 \mathrm{~m}$ (Chen et al., 2007), temperature and pressure of the Xujiahe Formation before the tectonic uplift can be calculated as $150^{\circ} \mathrm{C}$ and $60 \mathrm{MP}$ respectively. Using the data

in Table 2, average salinity of the formation water in the Xujiahe Formation is calculated as $234 \mathrm{~g} / \mathrm{L}$. Assuming salinity remains the same after tectonic uplift, volume of methane dissolved in unit volume of formation water can be calculated following Duan (1992). Results show that each unit volume of formation water can dissolve $4.56 \mathrm{~m}^{3}$ methane before the tectonic uplift, but only dissolve $2.16 \mathrm{~m}^{3}$ methane after the tectonic uplift. The tectonic uplift can release $2.4 \mathrm{~m}^{3}$ methane from each unit volume of formation water.

\subsection{Reservoir-forming process}


Source rocks of the Xujiahe Formation in the central Sichuan Basin entered the low-maturity stage $(\mathrm{Ro}=0.5 \%-0.6 \%)$ in the Middle Jurassic, representing the hydrocarbon-generation threshold from which hydrocarbon-supply into reservoirs started. From the Early Cretaceous to early stage of Late Cretaceous, these rocks were in moderate maturity stage $(\mathrm{Ro}=0.7 \%-1.0 \%)$. In late stage of Late Cretaceous, these rocks entered early stage of high-maturity period ( $\mathrm{Ro}=1.0 \%-1.3 \%)$. Both burial history and thermal evolution history of the Upper Triassic formation show that the source rocks of the Xujiahe Formation in central Sichuan Basin have massive hydrocarbon generation and discharging in Late Jurassic-Late Cretaceous (Fig. 2).

At the end stage of Late Cretaceous, formation temperatures and pressures decreased due to intensive tectonic uplifting and denudation of overlying formations in the Himalayan period. Subject to impacts of structural movements, micro-fractures were developed in reservoir formations. Such fractures can effectively enhance preservation capacities of these formations (Chen et al., 2014). At this time, hydrocarbon generation had already terminated. However, natural gas dissolved in water was released with decrease of pressures and temperatures. The natural gas released from water gradually formed free gas reservoirs or migrated into existing gas reservoirs.

\subsection{Reservoir-forming mode}

Natural gas generated by source rocks in the Xujiahe Formation is dissolved in surrounding water (Fig. 5a). When the dissolved gas is saturated in water, redundant natural gas may accumulate in structural highs of the reservoir formation as free gas. Since source rocks in the Xujiahe Formation have low hydrocarbon-generating potentials and sandstone reservoir formations are tight, reservoirs of free gas can be formed only in regional structures with high porosity and permeability (Fig. 5b).

At the end of Late Cretaceous, the central Sichuan Basin experienced large-scale uplift with denudation of relevant formations. With termination of hydrocarbon-generation in source rocks, temperatures and pressures of reservoir formations decreased gradually. Structural movements produced multiple fractures in reservoir formations to enlarge reservoir spaces in reservoir formations and to promote flow of fluids. In addition, natural gas dissolved in water was released under reduced pressures and temperatures. Large quantities of such natural gas were released into reservoir 
formations to form free gas (Fig. 5c).

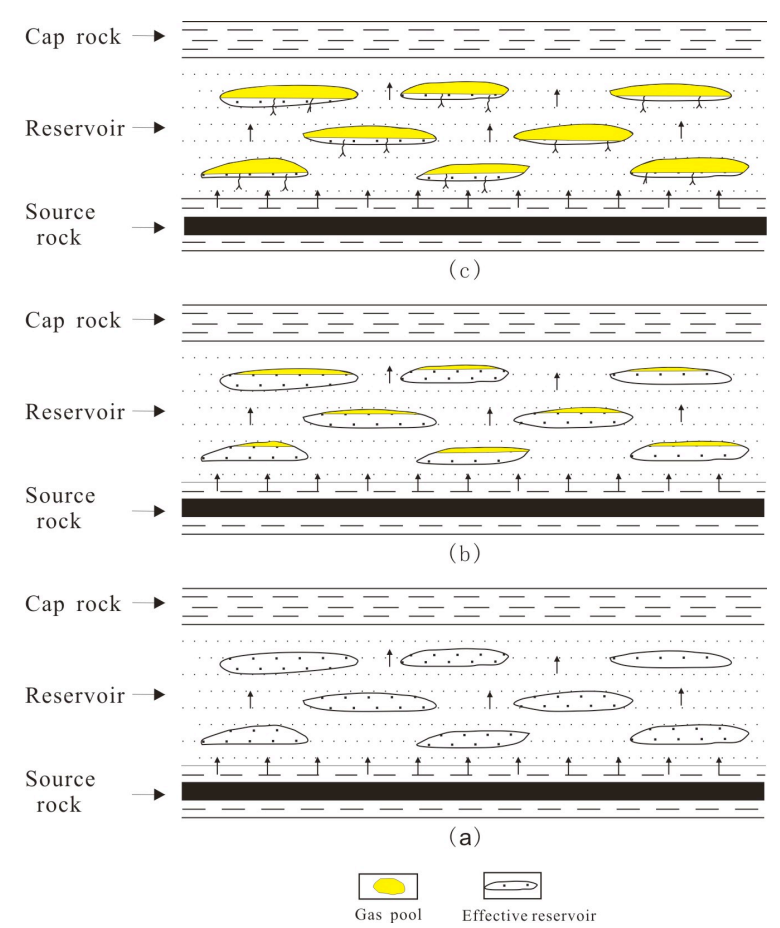

Fig.5 Natural gas accumulation pattern in Xujiahe Formation in central Sichuan Basin.

\section{Conclusions}

Gas reservoirs of the Xujiahe Formation in the central Sichuan Basin can be classified as reservoirs with gas generated and preserved in the same system. Source rocks contained in these formations have very low gas-generation intensity, but several large-scale gas fields with reserves over hundreds of billions of cubic meters have been discovered. Water-dissolved gas played vital roles in the formation of natural gas reservoirs. The Xujiahe Formation in central Sichuan Basin has extremely favorable conditions for generation of water-dissolved gas. The Himalayan structural movement significantly lifted the Xujiahe Formation to promote denudation of the overlying formations. As temperatures and pressures of gas reservoirs decreased dramatically, natural gas dissolved in water was released under reduced pressures and temperatures. Such released natural gas may form free gas reservoirs in structural highs of reservoir formations or migrate into existing gas reservoirs to increase reserves of gas reservoirs. During gas production, natural gas may be released into reservoir formations continuously due to the reduction of reservoir pressures. Production life of these gas reservoirs may be prolonged effectively by this mechanism. 


\section{Acknowledgements}

This study was jointly sponsored by National Natural Science Foundation of China (Grant No. 41372150), PetroChina Science and Technology Project (Grant No.2014B-0608), and RIPED Science and Technology Innovation Project (Grant No. 2012Y-001). We thank the editor for handling this manuscript and two reviewers for helpful comments and suggestions that have improved the manuscript.

\section{References}

Bian, C., Wang, H., Wang, Z., Li, Y., Zhu, r., Liu, L., 2009. Controlling factors for massive accumulation of natural gas in the Xujiahe Formation in central Sichuan Basin. Oil \& Gas Geology 30(5), 548-565 (in Chinese).

Bonham, L. C., 1978. Solubility of methane in water at elevated temperatures and pressure. AAPG 62(12), 2478 2481.

Che, G., Gong, C., Wang, N., Song, H., Li, J., 2007. Gas accumulation condition in the Xujiahe Group of Guang'an area. Natural Gas Industry 27(6), 1-5 (in Chinese).

Chen, H., Fu, X., Yang, J., 1997. Natural gases replenishment in Ya13-1 gas field in Ying-Qiong Basins, South China Sea. Acta Petrolei Sinica 18(4): 32-37 (in Chinese).

Chen, T., Jia, A., He, D., Shao, H., Ji, L., Yan. H., 2014. Mechanisms of gas-water distribution in tight sandstone gas reservoirs of Xujiahe Formation, central Sichuan Basin. Oil \& Gas Geology 35(2): 218-223 (in Chinese).

Chen, Y., Jiang, Y., Guo, G., Yang, J., 2007. Simulation of the source rock thermal evolution history of Xiangxi Group of Upper Trassic in central Sichuan area. Journal of Southwest Petroleum University 29(2), 57-60 (in Chinese).

Colin, B., 1987. Development of abnormal and subnormal pressures in reservoirs containing bacterially generated gas. AAPG 71(11), 1404 1413.

Cramer, B., Poelchau, H. S., Gerling, P., Lopatin, N. V., Littke, R., 1999. Methane released from groundwater: the source of natural gas accumulations in Northern West Siberia. Marine and Petroleum Geology 16: 225-244.

Dai, J., 1979. The oil and gas generation during coalification. Petroleum Exploration and Development 
6(3), 10-17 (in Chinese).

Dai, J., 1992. Identification and distribution of various alkane gases. Science in China (Series B) $35(10), 1246-1257$.

Dai, J., Wang, T., Song, Y., Zhang, H., Xu, Y., Zhang, Q., 1997. Formation and distribution of medium-large-sized gas field in China. Geological Publishing House, Beijing (in Chinese).

Dai, J., Ni, Y., Zou, C., Tao, S., Hu, G., Hu, A., 2009. Stable carbon isotopes of alkane gases from the Xujiahe coal measures and implication for gas-source correlation in the Sichuan Basin, SW China. Organic geochemistry 40(5), 638-646.

Dai, J., Ni, Y., Zou C., 2012. Stable carbon and hydrogen isotopes of natural gases source from the Xujiahe Formation in the Sichuan Basin, China. Organic geochemistry 43(1), 103-111.

Duan, Z., Moller, N., Greenberg, J., Weare, J. H., 1992. The prediction of methane solubility in natural waters to high ionic strength from 0 to $250^{\circ} \mathrm{C}$ and from 0 to 1600 bar. Geochimica et Cosmochimica Acta 56: 1451-1460.

Hao, G., Liu, G., Xie, Z., Sun, M., 2010a. Gas-water distributed pattern in Xujiahe Formation tight gas sandstone reservoir and influence factor in Central Sichuan Basin. Natural Gas Geoscience 21(3), 427-434 (in Chinese).

Hao, G., Liu, G., Xie, Z., Sun, M., 2010b. Distribution characteristics of gas and water of tight sandstone gas reservoir in Upper Triassic Xujiahe Formation of Guangan gas field. Journal of China University of Petroleum 34(3), 1-7 (in Chinese).

International Atomic Energy Agency, 1995. Reference and intercomparison materials for stable isotopes of light elements.

Jiang, Y., Guo, G., Chen, Y., Li, Z., Lu, Z.,2006. Mechanism of gas reservoiring in Xujiahe Formation in central Sichuan Basin. Natural Gas Industry 26(11), 1-3 (in Chinese).

Li, M., Li, Q., Zhang, Q., Peng, Y., Wang, H., Lu, Y., 2003. Deep water-soluble natural gas at the thrust-uplift belt in Kuche Foreland Basin. Natural Gas Geoscience 14(5): 366-370 (in Chinese).

Littke, R., Cramer, B., Gerling, P., Lopatin, N. V., Poelchau, H. S., Schaefer, R. G., Welte, D. H., 1999. Gas generation and accumulation in the West Siberian Basin. AAPG Bulletin 83(10): $1642-1665$.

Liu, H., Xing, H., Jiang, Z., Wang, Y., 2005. Resource predication and exploration of Xujiahe 
Formation in center of Chuanxi foreland basin. Coal Geology \& Exploration 33(1), 25-27 (in Chinese).

Liu, S., Sun, W., Li, Z., Deng, B., Liu, S., 2008. Tectonic uplifting and gas pool formation since Late Cretaceous Epoch. Natural Gas Geoscience 19(3): 293-300 (in Chinese).

Qin, S., Zhao, J., Li, M., Liu, Y., 2006. A case study: geochemical tracing indices on the migration of water- soluble gases in Hetianhe Gas Field, Tarim Basin. Earth Science Frontiers 13(5): 524-532 (in Chinese).

Qin, S., Li, M., Hu, J., Zhang, Q., LV Y., 2007. Inplication to Kela 2 field from water-soluble gas accumulation in Hetianhe gas field [J]. Natural Gas Geoscience 18(1): $45-49$ (in Chinese).

Qin, S., Yang, Y., Lv, F., Zhou, H., Li, Y., 2016. The gas origin in Changxing-Feixianguan gas pools of Longgang gas field in Sichuan Basin. Natural Gas Geoscience 27(1): 40-48 (in Chinese).

Shanley, K. W., Cluff, R. M., Robinson, J. W., 2004. Factors controlling prolific gas production from low-permeability sandstone reservoirs. AAPG Bulletin 88(8): 1083-1121.

Tao, S., Zou, C., Tao, X., Huang, C., Zhang, X., Gao, X., Li, W., Li, G., 2009. Study on fluid inclusion and gas accumulation mechanism of xujiahe formation of Upper Triassic in the Central Sichuan Basin. Bulletin of Mineralogy, Petrology and Geochemistry, 28(1): 2-11.

Tian, L., He, S., Liu, S., Lan, Z., 2009. Features of gas and water distribution in the Xujiahe Formation gas reservoir of Guang'an area. Natural Gas Industry 29(6), 23-26 (in Chinese).

Wang, L., Gou, X., Liu, G., Wang, L., Wang, W., Wang, M., 1997. The organic geochemistry and origin of natural gases in Sichuan Basin. Acta Sedimentologica Sinica 15(2): $49-53$ (in Chinese).

Wang, Q., Zhang, Z., Zhong, N., Zhang, S., Li, Y., et al., Liu, H., Wen, J., 2004. Influence of solution-releasing on gas reservoir formation - taking Kela-2 Gas Field as an example. Natural Gas Industry 24(6): 18-21 (in Chinese).

Wang, W., Xu, G., Yong, Z., Yuan, H., 2005. Distribution rule and formation mechanism of gas and water in Layer 4 of Xiangxi Group of the central area in Sichuan, China. Journal of Chengdu University of Technology (Science \& Technology Edition) 32(4), 378-382 (in Chinese).

Wang, Y., Yu, X., Yang, Y., Zhang, J., 1998. Applications of fluid inclusions in the study of paleo-geotemperature in Sichuan Basin. Earth Science-Journal of China University of Geoscience 23(3): 285-288 (in Chinese). 
Xiao, Z., Xie, Z., Li, Z., Ma, C., 2008. Isotopic characteristics of natural gas of Xujiahe Formation in southern and middle of Sichuan Basin. Geochimica 37(3), 245-250 (in Chinese).

Xie, J., Zhang, J., Li, G., Tang, D., Peng, J., 2008. Exploration prospect and gas reservoir characteristics of Xujiahe Formation in Sichuan Basin. Journal of Southwest Petroleum University ( Science \& Technology Edition) 30(6), 40-44 (in Chinese).

Xie, J., Li, G., Luo, F., 2009. Reservoir Characteristics of the Upper Triassic Xujiahe Formation in Sichuan Basin, China. Journal of Chengdu University of Technology ( Science \& Technology Edition) 36(1),13-18 (in Chinese).

Xu, Y., He, Z., Zeng, F., 2004. Characteristics of gas accumulation in Northeastern Sichuan Basin. Oil \& Gas Geology 25(3): 274-278 (in Chinese).

Xu, Z., Song, L., Wu, X., Chen, C., 2009. Typical gas reservoir and main controlling factors of reservoir-forming of Upper Triassic Xujiahe Formation in central Sichuan Basin. Lithologic Reservoirs 21(2), 7-11 (in Chinese).

Yang, W., Xie, Z., Jin, H., Shi, Z., Xie, W., 2010. Reservoir evaluation and pooling mechanism of the Xujiahe formation in the Sichuan Basin. Natural Gas Industry 30(12), 10-15 (in Chinese).

Yang, Y., Wang, S., Huang, L., Zhong, J., 2009. Features of source rocks in the Xujiahe Formation at the transitional zone of central southern Sichuan Basin. Natural Gas Industry 29(6), 27-30 (in Chinese).

Yi, S., Lin, S., Yang, W., Shi, Z., Li, J., 2013. Condition of Xujiahe Formation large gas province formation in Sichuan Basin. Natural Gas Geoscience 24(1), 1-8 (in Chinese).

Zhang, X., Zou, C., Zhu, R., Tao S., Yang, S., 2011. Reservoir diagenetic facies of the Upper Triassic Xujiahe Formation in the central Sichuan Basin. Acta Petrolei Sinica 32(2), 257-264 (in Chinese).

Zhao, W., Wang, H., Xu, C., Bian, C., Wang, Z., Gao, X., 2010. Reservoir-forming mechanism and enrichment conditions of the extensive Xujiahe Formation gas reservoirs, central Sichuan Basin. Petroleum Exploration and Development 37(2), 146-157.

Zhao, W., Bian, C., Xu, C., Wang, H., Wang, T., Shi, Z., 2011. Assessment on gas accumulation potential and favorable plays within the Xu-1, 3 and 5 member of Xujiahe Formation in Sichuan Basin. Petroleum Exploration and Development 38(4), 385-393 (in Chinese).

Zeng, Q., Gong, C., Li, J., Che, G., Lin, J.,2009. Exploration achievements and potential analysis of 
gas reservoirs in the Xujiahe Formation, central Sichuan Basin. Natural Gas Industry 29(6), 13-18 (in Chinese).

Zou, C., Tao, S., Zhu, R., Yuan, X., Li, W., Zhang, G., Zhang, X., Gao, X., Liu, L., Xu, C., Song, J., Li, G., 2009. Formation and distribution of"continuous"'gas reservoirs and their giant gas province: A case from the Upper Triassic Xujiahe Formation giant gas province, Sichuan Basin. Petroleum Exploration and Development 36(3): 307-319 (in Chinese). 